\title{
ПОВНОВАЖЕННЯ ПІДРОЗДІЛІВ ПОЛІЦІї ПРЕВЕНТИВНОЇ ДІЯЛЬНОСТІ ЩОДО ЗАПОБІГАННЯ ДОМАШНЬОМУ НАСИЛЬСТВУ
}

Волокітенко І. 0 .

\begin{abstract}
у статmі розкриваються повноваження підрозділів превентивної діяльності Національної поліції України у сфері запобігання та протидії домашньому насильству, досліджено шляхи вдосконалення діяльності превентивних підрозділів Національної поліції України у сфері запобігання домашньому насильству. Проаналізовано основні нормативно-правові акти України, якими реґламентується вжиття невідклад-
\end{abstract} них заходів із запобігання та протидії домашньому насильству, насильству за ознакою статі, захисту прав осіб, які постраждали від такого насильства. Визначено, що до законодавства України у сфері протидї та запобігання домашньому насильству належать законодавчі та підзаконні, відомчі, нормативно-правові акти. До основних завдань та методів діяльності підрозділів превентивної діяльності Національної поліції України віднесено: виявлення фактів домашнього насильства та своєчасне реагування на них; прийом і розгляд заяв та повідомлень про вчинення домашнього насильства, зокрема й розгляд повідомлень, що надійшли до колцентру з питань запобігання та протидії домашньому насильству, насильству за ознакою статі та насильству стосовно дімей, ужиття заходів для його припинення та надання допомоги постраждалим особам з урахуванням результатів оцінки ризиків у порядку, визначеному центральним органом виконавчої влади, що забезпечує формування державної політики у сфері запобігання та протидії домашньому насильству, спільно з Національною полічією України тощо. Автором зазначено, що підрозділи органів Начіональної поліції України здійснюють повноваження у сфері запобігання та протидіі домашньому насильству з урахуванням міжнародних стандартів реагування правоохоронних органів на випадки домашнього насильства й оцінки ризиків. Названо загальні та сnеціальні заходи, що застосовуються до кривдників, а також зазначено особливості їх застосування підрозділами превентивної діяльності Національної поліції України у сфері запобігання та протидіі домашньому насильству. Особливу увагу приділено веденню профілактичного обліку кривдників та проведення з ними профілактичної роботи підрозділом органу Національної поліції України. Розглянуто функції підрозділів поліції превентивної діяльності та розроблено пропозиції щодо внесення організацій- но-штатних змін у структуру територіальних органів та підрозділів поліції.

Ключові слова: Національна поліція України, функції поліціі, підрозділи поліції, превентивна діяльності, домашнє насильство.

Volokitenko I. O. Powers of the preventive police units in terms of the domestic violence prevention

The article covers the powers of preventive units of the National Police of Ukraine in the field of prevention and counteraction to domestic violence, studies ways to improve the activities of preventive units of the National Police of Ukraine in the field of prevention of domestic violence. The fundamental normative legal acts of Ukraine, which regulate the taking of urgent measures to prevent and combat domestic violence, gender-based violence, protection of the rights of persons who have suffered from such violence, are analyzed. It is determined that the legislation of Ukraine in the field of counteraction and prevention of domestic violence includes legislative acts, and by-laws, departmental, normative-legal acts. The main tasks and methods of activity of the preventive units of the National Police of Ukraine include: finding of the facts of domestic violence and timely response to them; acceptance and examination of statements and reports of domestic violence, including consideration of reports received by the call center for the prevention and combating against domestic violence, gender-based violence and violence against children, taking measures to stop it and providing assistance to victims, given the results of risk assessment in the manner prescribed by the central executive body, which ensures the formation of state policy in the field of preventing and combating domestic violence, together with the National Police of Ukraine, etc. The author analyzes that the units of the National Police of Ukraine exercise powers in the field of prevention and counteraction to domestic violence, taking into account international standards of response of law enforcement agencies to cases of domestic violence and risk assessment. The general and special actions applied to offenders are specified, and features of their application by the preventive units of the National Police of Ukraine in the field of prevention

(c) Волокітенко І. О., 2020 
and counteraction to domestic violence are noted as well. Particular attention is paid to the preventive accounting of offenders and maintenance of preventive activity for them by $a$ unit of the National Police of Ukraine. The functions of police preventive units are considered, and proposals for making organizational and staffing changes in the structure of territorial bodies and police units are developed.

Key words: National Police of Ukraine, police functions, police units, prevention, preventive activities, domestic violence.

Постановка проблеми та іï актуальність. Наближення стандартів професійної підготовки та службової діяльності щодо запобігання домашньому насильству підрозділів поліції превентивної діяльності Національної поліції України до загальновизнаних у міжнародних відносинах норм і стандартів, а також до відповідних стандартів європейських та інших країн $є$ одним з основних напрямів реформування системи правоохоронних органів України. Відповідно до нового адміністративнотериторіального устрою, згідно з постановою Верховної Ради України від 17 липня 2020 р. № 807-ІХ «Про утворення та ліквідацію районів»[1], натепер запроваджуються нові організаційно-штатні зміни у структурі територіальних органів, підрозділів поліції, що зумовлює розроблення та визначення таких категорій: цілей, завдань діяльності, структурно-організаційних і компетенційних елементів, спрямованих на забезпечення прав і свобод людини, інтересів суспільства й держави, запобігання домашньому насильству.

Аналіз останніх досліджень і публікацій. Загальнотеоретичним аспектам організаційно-правових основ діяльності поліції України присвячено праці вчених-адміністративістів: О.М. Бандурки, О.І. Безпалової, С.М. Гусарова, О.В. Джафарової, О.С. Доценко, О.М. Зайця, Д.П. Калаянова, В.В. Конопльова, О.В. Кузьменко, Є.В. Курінного, О.В. Негодченка, А.В. Панчишина, К.М. Рудой, Ю.В. Сіроштана, С.О. Шатрави й інших. Стосовно ж дослідження цілей, завдань, форм та методів діяльності підрозділів превентивної служби Національної поліції України щодо запобігання домашньому насильству на теренах сучасного українського адміністративного законодавства та в контексті реформування системи Міністерства внутрішніх справ (далі - МВС) України існують лише поодинокі наукові розробки.

Метою статті $\epsilon$ визначення повноважень підрозділів поліції превентивної діяльності щодо запобігання домашньому насильству, а також розкриття основних організаційно-правових форм, методів та заходів у сфері запобігання домашньому насильству.

Виклад основного матеріалу. Відповідно до п. 5 ст. 1 Закону України «Про запобігання та протидію домашньому насильству», запобігання домашньому насильству - система заходів, що здійснюються органами виконавчої влади, органами місцевого самоврядування, підприємствами, установами й організаціями, а також громадянами України, іноземцями й особами без громадянства, які перебувають в Україні на законних підставах, та спрямовані на підвищення рівня обізнаності суспільства щодо форм, причин і наслідків домашнього насильства, формування нетерпимого ставлення до насильницької моделі поведінки у приватних стосунках, небайдужого ставлення до постраждалих осіб, насамперед до постраждалих дітей, викорінення дискримінаційних уявлень про соціальні ролі й обов'язки жінок і чоловіків, а також будь-яких звичаїв і традицій, що на них ґрунтуються.

До повноважень підрозділів превентивної діяльності Національної поліції України у сфері запобігання та протидії домашньому насильству належать:

1) виявлення фактів домашнього насильства та своєчасне реагування на них;

2) прийом і розгляд заяв та повідомлень про вчинення домашнього насильства, зокрема й розгляд повідомлень, що надійшли до колцентру з питань запобігання та протидії домашньому насильству, насильству за ознакою статі та насильству стосовно дітей, ужиття заходів для його припинення та надання допомоги постраждалим особам з урахуванням результатів оцінки ризиків у порядку, визначеному центральним органом виконавчої влади, що забезпечує формування державної політики у сфері запобігання та протидії домашньому насильству, спільно з Національною поліцією України;

3) інформування постраждалих осіб про їхні права, заходи і соціальні послуги, якими вони можуть скористатися;

4) винесення термінових заборонних приписів стосовно кривдників;

5) взяття на профілактичний облік кривдників та проведення з ними профілактичної роботи в порядку, визначеному законодавством;

6) здійснення контролю за виконанням кривдниками спеціальних заходів протидії домашньому насильству протягом строку їхньої дії;

7) анулювання дозволів на право придбання, зберігання, носіння зброї та боєприпасів їхнім 

та науково-методичне забезпечення

власникам у разі вчинення ними домашнього насильства, а також вилучення зброї та боєприпасів у порядку, визначеному законодавством;

8) взаємодія з іншими суб'єктами, що здійснюють заходи у сфері запобігання та протидії домашньому насильству, відповідно до ст. 15 цього Закону;

9) звітування центральному органу виконавчої влади, що реалізує державну політику у сфері запобігання та протидії домашньому насильству, про результати здійснення повноважень у цій сфері в порядку, визначеному центральним органом виконавчої влади, що забезпечує формування державної політики у сфері запобігання та протидії домашньому насильству.

Уповноважені підрозділи органів Національної поліції України здійснюють повноваження у сфері запобігання та протидії домашньому насильству з урахуванням міжнародних стандартів реагування правоохоронних органів на випадки домашнього насильства й оцінки ризиків. Поліцейські можуть проникати до житла особи без вмотивованого рішення суду в невідкладних випадках, пов'язаних із припиненням вчинюваного акту домашнього насильства, у разі безпосередньої небезпеки для життя чи здоров'я постраждалої особи.

Окремо варто зазначити, що відповідно до наказу МВС від 19 грудня 2017 р. № 1044 «Про затвердження Інструкції з організації роботи підрозділів ювенальної превенції Національної поліції України» [4], основними завданнями є:

профілактична діяльність, спрямована на запобігання вчиненню дітьми кримінальних і адміністративних правопорушень, виявлення причин і умов, які цьому сприяють, ужиття в межах своєі компетенції заходів для їх усунення;

- ведення профілактичного обліку дітей, схильних до вчинення правопорушень, та проведення з ними заходів індивідуальної профілактики;

участь в установленні місцезнаходження дитини в разі іï безвісного зникнення чи отриманні даних для цього в межах кримінального провадження, відкритого за фактом іï безвісного зникнення;

ужиття заходів щодо запобігання та протидії домашньому насильству, учиненому дітьми та стосовно них, а також жорстокому поводженню з дітьми;

ужиття заходів щодо запобігання дитячій бездоглядності, зокрема i здійснення поліцейського піклування щодо неповнолітніх осіб;
- провадження діяльності, пов'язаної із захистом права дитини на здобуття загальної середньої освіти.

До спеціальних заходів щодо протидії домашньому насильству належать:

1) терміновий заборонний припис стосовно кривдника;

2) обмежувальний припис стосовно кривдника;

3) взяття на профілактичний облік кривдника, проведення з ним профілактичної роботи;

4) направлення кривдника на проходження програми для кривдників.

Відповідно до п. 16 ст. 1 Закону України «Про запобігання та протидію домашньому насильству», терміновий заборонний припис - це спеціальний захід протидії домашньому насильству, що вживається уповноваженими підрозділами органів Національної поліції України як реагування на факт домашнього насильства та спрямований на негайне припинення домашнього насильства, усунення небезпеки для життя і здоров'я постраждалих осіб та недопущення продовження чи повторного вчинення такого насильства[3].

Цей припис виноситься в разі наявності безпосередньої загрози життю чи здоров'ю постраждалої особи 3 метою негайного припинення домашнього насильства, недопущення його продовження чи повторного вчинення. Детальніше цей юридичний інструмент реґламентований у ст. 25 цього Закону.

Заходи, які можуть бути застосовані на підставі термінового заборонного припису, включають: (1) зобов' язання для кривдника (особа, яка вчинила домашнє насильство) залишити місце проживання (перебування) постраждалої особи; (2) заборону кривднику на вхід та перебування в місці проживання (перебування) постраждалої особи; (3) заборону кривднику в будь-який спосіб контактувати з постраждалою особою. Стосовно неповнолітніх кривдників, які мають спільне місце проживання (перебування) з постраждалою особою, зазначені перші два заходи не підлягають застосуванню.

Необхідно наголосити, що Закон України «Про запобігання та протидію домашньому насильству» надає безпеці постраждалої особи пріоритет навіть над майновими правами осіб на житло [3]. Тому в ч. 3 ст. 25 цього Закону передбачено можливість винесення термінового заборонного припису стосовно житлового приміщення, яке належить винятково кривднику, за умови, що таке житло $\epsilon$ місцем спільного проживання (перебування) постраждалої особи та кривдника. Водночас поліція наділяється повноваженням здійснити висе- 
лення кривдника з такого житлового приміщення, якщо терміновий заборонний припис передбачає зобов'язання залишити місце проживання (перебування) постраждалої особи, а кривдник відмовляється добровільно його залишити. Нагальність i позасудовий характер ухвалення зумовлюють строк дії термінового заборонного припису, який становить не більше десяти днів.

Отже, терміновий заборонний припис застосовується поліцією в разі наявності загрози для потерпілої особи та з метою негайної протидії акту домашнього насильства. Тобто на момент винесення цього припису особа, стосовно якої він виноситься, не визнана винною у вчиненні домашнього насильства у кримінальному провадженні чи справі про адміністративне правопорушення. Загалом цей підхід дещо нагадує затримання підозрюваної особи під час вчинення злочину або після його вчинення, якщо сукупність ознак вказує на те, що саме ця особа вчинила злочин (ст. 208 Кримінального процесуального кодексу), яке відбувається до початку досудового розслідування (інакше кажучи, до «відкриття кримінального провадження»). За цією аналогією, на нашу думку, винесення термінового заборонного припису повинно супроводжуватися іншими процесуальними діями поліції, а саме складенням протоколу про адміністративне правопорушення (ст. 173-2 Кодексу України про адміністративні правопорушення) або ж внесенням відомостей про відповідне кримінальне правопорушення до Єдиного реєстру досудових розслідувань.

На відміну від термінового заборонного припису, обмежувальний припис виноситься судом на підставі звернення зацікавлених осіб, а тому допускає значно ширше коло можливих обмежень прав кривдника, більш тривалі строки. Зокрема, заходами, які можуть бути застосовані до кривдника на підставі обмежувального припису, $\epsilon$ : (1) заборона перебувати в місці спільного проживання (перебування) з постраждалою особою; (2) усунення перешкод у користуванні майном, що $€$ об'єктом права спільної сумісної власності або особистою приватною власністю постраждалої особи; (3) обмеження спілкування з постраждалою дитиною; (4) заборона наближатися на визначену відстань до місця проживання (перебування), навчання, роботи, інших місць частого відвідування постраждалої особи; (5) заборона особисто і через третіх осіб розшукувати постраждалу особу, якщо вона за власним бажанням перебуває в місці, невідомому кривднику, переслідувати іï та в будь-який спосіб спілкуватися
3 нею; (6) заборона вести листування, телефонні переговори з постраждалою особою або контактувати з нею через інші засоби зв'язку особисто і через третіх осіб. Варто зауважити, що обмежувальний припис може передбачати застосування одразу кількох зазначених заходів. Аналогічно до термінового заборонного припису обмежувальний припис не може містити заходів, що обмежують право проживання чи перебування неповнолітнього кривдника в місці свого постійного проживання (перебування). Видача обмежувального припису здійснюється шляхом ухвалення рішення суду в порядку окремого провадження, для цілей чого розд. IV Цивільного процесуального кодексу (далі - ЦПК) доповнено новою гл. 13. Крім того, видача обмежувального припису в порядку окремого провадження ґрунтується на положенні, що це провадження призначене для створення умов для здійснення особою особистих немайнових чи майнових прав (ч. 7 ст. 19 ЦПК). Обмежувальний припис видається на строк від одного до шести місяців та може бути продовжений судом на строк не більше шести місяців[12].

Закон України «Про запобігання та протидію домашньому насильству» та ЦПК не передбачають можливості скасування обмежувального припису, зокрема в разі визнання особи невинуватою у вчиненні злочину чи адміністративного правопорушення. Видається, що можливим способом вирішення цього питання буде скасування рішення суду за нововиявленими обставинами.

Крім того, усі факти домашнього насильства, інформація про кривдника (незалежно від його згоди), а також про постраждалих (за їхньою згодою) вносяться до Єдиного державного реєстру випадків домашнього насильства та насильства за ознакою статі. Така інформація зберігається в базі: 1 рік - у разі відсутності відкритого кримінального провадження, судового рішення про обмежувальний припис або адміністративне стягнення, обвинувального вироку суду; 3 роки у разі наявності судового рішення про обмежувальний припис або адміністративне стягнення; 10 років - у разі наявності обвинувального вироку, який набрав чинності.

До того ж кривдника можуть взяти на профілактичний облік, проводити з ним роботи органами поліції, направити на проходження програми виправних робіт на строк від трьох місяців до одного року.

Наступний захід - взяття підрозділом органу Національної поліції України на профілактичний облік кривдників, проведення з ними профілак- 
тичної роботи, наступає з моменту виявлення факту вчинення ними домашнього насильства, на встановлений законодавством строк. Зняття кривдника із профілактичного обліку здійснюється уповноваженим підрозділом органу Національної поліції України, який взяв його на профілактичний облік, автоматично після завершення встановленого строку, якщо інше не передбачено законодавством. Порядок взяття на профілактичний облік, проведення профілактичної роботи та зняття із профілактичного обліку кривдника затверджується Міністерством внутрішніх справ України.

У свою чергу, існує виконання програм для кривдників. Суб'єктами, відповідальними за виконання програм для кривдників, $є$ місцеві державні адміністрації й органи місцевого самоврядування, які організовують та забезпечують проходження кривдниками таких програм. Виконання програм для кривдників стосовно дітей-кривдників здійснюється з урахуванням вікових та психологічних особливостей дітей. 3 метою запобігання повторному вчиненню домашнього насильства та забезпечення виконання програми для кривдника дитину кривдника може бути тимчасово влаштовано до родичів, у сім'ю патронатного вихователя або до установи для дітей незалежно від форми власності та підпорядкування, у яких створені належні умови для проживання, виховання, навчання та реабілітації дитини відповідно до її потреб. Виконання програм для кривдників забезпечують фахівці, які пройшли відповідне навчання. Кривдника може бути направлено судом на проходження програми для кривдників на строк від трьох місяців до одного року у випадках, передбачених законодавством. Кривдник повинен мати можливість відвідувати програму для кривдників за власною ініціативою на добровільній основі. У разі неявки кривдника для проходження програми для кривдників або ухилення від проходження програми без поважних причин суб'єкти, відповідальні за виконання програм для кривдників, надають протягом трьох робочих днів письмове повідомлення про це уповноваженому підрозділу органів Національної поліції України для вжиття заходів. Притягнення кривдника до відповідальності за непроходження програми для кривдників не звільняє його від обов'язку пройти таку програму. У разі притягнення кривдника, зокрема дитини-кривдника, до кримінальної відповідальності судом на нього може бути покладено обов'язок пройти пробаційну програму відповідно до п. 4 ч. 2 ст. 76 Кримінального кодексу України [12].

Необхідно зауважити, усі ці заходи є запобіжними, які дозволяють державним органам опера- тивно зреагувати на факти домашнього насильства, припинити його вчинення, усунути загрозу повторного насильства. Проте застосування таких заходів зовсім не означає, що кривдника не притягнуть до адміністративної або кримінальної відповідальності за наявності підстав.

3 метою дотримання прав і свобод людини, додержання гарантій із захисту прав та інтересів осіб, які постраждали від домашнього насильства, насильства за ознакою статі, а також забезпечення належного реагування на випадки такого насильства, надання допомоги постраждалим особам, створення умов для реалізації кожною дитиною права на зростання в безпечному сімейному оточенні, зважаючи на зростання викликів, пов'язаних із вчиненням домашнього насильства, унаслідок зменшення латентності таких правопорушень, великий суспільний резонанс та з метою ефективної реалізації Указу Президента України від 21 вересня 2020 р. № 398/2020 «Про невідкладні заходи із запобігання та протидії домашньому насильству, насильству за ознакою статі, захисту прав осіб, які постраждали від такого насильства» пропонуємо в кущових підрозділах поліції, які створені на базі обласних центрів та містах Сєвєродонецьк і Маріуполь, у відділах превенції створити сектори протидії домашньому насильству, до складу яких, зокрема, будуть входити поліцейські, задіяні в роботі в мобільних групах із реагування на факти вчинення таких правопорушень, які нині успішно функціонують у межах реалізації відповідного проєкту.

Пропонуємо штатний розпис вказаного сектора налічувати від 10 посад на одну мобільну групу (залежно від кількісного навантаження викликів про факти вчинення домашнього насильства) з розрахунку: 1 - начальник сектора, 1 - старший інспектор та інспектори.

3 огляду на те, що не в кожному територіальному (відокремлений) підрозділі поліції згідно зі штатним розписом є посада інспектора ювенальної превенції або ж така посада лише одна, пропонуємо у відділі превенції районних (кущових) управлінь відповідного нового адміністративно-територіального устрою районів створити сектори ювенальної превенції за рахунок штатних посад поліцейських ювенальної превенції відділів (відділень) поліції, які обслуговують територію цих районів.

Водночас частково повноваження за лінією ювенальної превенції на рівні цих підрозділів поліції виконуватимуть дільничні офіцери поліції, поліцейські офіцери громади (відповідні зміни 
внесено до наказу Міністерства внутрішніх справ № 650 від 28 липня 2017 р. «Про затвердження Інструкції з організації діяльності дільничних офіцерів поліції») та, як виняток, інспектори ГРПП, зокрема:

ужиття заходів щодо встановлення особи дитини, місця іï проживання, відомостей про батьків або осіб, які їх замінюють, інших родичів, місця їх проживання (перебування), у разі надходження повідомлення про дитину, яка залишилась без батьківського піклування (щодо випадків, які не потребують відкриття кримінального провадження та заведення ОРС «Розшук»);

ужиття, у разі безпосередньої загрози життю або здоров'ю дитини, заходів до відібрання дитини в батьків та тимчасового влаштування іï відповідно до чинного законодавства;

здійснення роботи із запобігання вчиненню правопорушень.

Такий розподіл повноважень дозволить «розгрузити» поліцейських ювенальної превенції за некритичними випадками, уживати заходів щодо якісної профілактичної роботи, імплементації кращого міжнародного досвіду поліції щодо роботи з дітьми, розшуку безвісти зниклих дітей, які можуть стати жертвами злочинів, виявляти правопорушення стосовно дітей та їх документувати. Сектор ювенальної превенції надає методичну допомогу та координує виконання завдань між секторами дільничних офіцерів поліції, поліцейських офіцерів громади та груп реагування патрульної поліції.

Відділ реагування патрульної поліції організовує роботу груп реагування патрульної поліції (далі - ГРПП) у межах території обслуговування району. Надає їм практичну та методичну допомогу в підвищенні ефективності роботи, взаємодіє під час вирішення цих питань із ВРПП інших районних управлінь (відділів) ГУНП в області, іншими структурними підрозділами Національної поліції, органами місцевого самоврядування, підприємствами, установами, організаціями всіх форм власності, громадянами. Відділу підпорядкувати ГРПП - наряди у складі не менше двох поліцейських, які нестимуть службу у дві зміни по 12 годин на добу на території обслуговування всього районного управління (відділу).

Також у територіальних відділеннях поліції (далі - ТВП) районного управління (відділу) поліції, які розташовані в межах понад 25 км від районного управління і в яких передбачено несення служби 2 та більше ГРПП в одну зміну, створюється сектор реагування патрульної поліції (далі - СРПП) у складі начальника сектора, старшого інспектора й інспекторів (поліцейські) ГРПП. СРПП базується на території ТВП, де зберігається їхня табельна вогнепальна зброя, спецзасоби, службові транспортні засоби, пально-мастильні матеріали та службова документація. Водночас СРПП виводиться з підпорядкування ТВП та безпосередньо підпорядковується ВРПП районного управління (відділу). Контроль за їхньою службовою діяльністю безпосередньо здійснює начальник СРПП і уповноважені інспектори сектора адмінпрактики.

За аналогічних умов, але несення служби передбачено лише 1 ГРПП в одну змін, безпосереднє підпорядкування здійснюється начальникові СРПП найближчого за територіальністю, у межах району обслуговування.

У ТВП районного управління (відділу) поліції, які розташовані в межах 50 км від районного управління та в яких передбачено несення служби 1 ГРПП в одну зміну, сектор реагування патрульної поліції не створюється. ГРПП базується на території ТВП, де зберігається їхня табельна вогнепальна зброя, спецзасоби, службові транспортні (транспортний) засоби та службова документація. Водночас ГРПП виводиться з підпорядкування ТВП та безпосередньо підпорядковується ВРПП районного управління (відділу).

Обслуговування території відділення поліції здійснюватимуть поліцейські відділу реагування патрульної поліції та/або сектора реагування, найближчого за територіальністю. Навантаження на одного поліцейського територіальних підрозділів превенції та на один наряд реагування патрульної поліції розраховувати з кількості населення на визначеній території обслуговування, кількості населених пунктів, протяжності вулично-шляхової мережі, площі території обслуговування та стану криміногенної ситуації. Пропонується відійти від методології розрахунків 1 наряд ГРПП на 25 тисяч населення та, як приклад, запровадити розрахунок одного наряду на площу у квадратних кілометрах.

Пропонуємо розширити функціональні напрями роботи сектора адміністративної практики, а саме щодо запобігання домашньому насильству: забезпечення взаємодії із черговими службами територіальних управлінь (відділів) поліції; забезпечення методичного супроводження діяльності нарядів ГРПП, дільничних офіцерів поліції, поліцейських офіцерів громад (далі - наряди); здійснення цілодобового моніторингу та контролю за службовою діяльністю нарядів, а також виконання ними службових завдань, зокрема i створених самостійно; надсилання, за погодженням з опера- 
тивним черговим районного управління, нарядам електронних службових завдань та контроль за їх виконанням; здійснення контролю за станом адміністративної діяльності як районного управління (відділу) поліції, так і його територіальних підрозділів; у межах компетенції здійснювати координацію з районними судами у справах про адміністративні правопорушення, зважаючи на те, що система судоустрою на практиці не завжди може збігатися з новоутвореним адміністративно-територіальним устроєм, це дає підстави вважати, що місцеві суди продовжують здійснювати розгляд справ у межах раніше визначених районів.

Під час розгляду питання щодо виділення службового приміщення під поліцейську станцію враховується можливість розміщення в ньому для спільної роботи інспекторів ювенальної превенції, дільничних офіцерів поліції, поліцейських офіцерів громад, їхніх помічників, поліцейських відділів реагування та забезпечення належними умовами для виконання покладених на них службових завдань. Службова діяльність зазначених структурних підрозділів організовується відповідно до вимог чинного законодавства України та відомчих нормативно-правових актів, які реґламентують діяльність поліцейських, закріпити їх за поліцейськими дільницями та територіями обслуговування підрозділів реагування в межах ОТГ.

Висновки. Запобігання домашньому насильству $\epsilon$ одним із пріоритетних напрямів поліції превентивної діяльності, до складу якої входять відділи дільничних офіцерів поліції, підрозділи ювенальної превенції, патрульної поліції тощо. Забезпечення ефективності такої діяльності варто супроводжувати помітним для населення підсиленням технічної забезпеченості поліції, підвищенням ефективності роботи, ужиттям низки інших організаційних заходів, удосконаленням правового регулювання діяльності з метою протидії та запобігання домашньому насильству, що зумовлюють компетенцію й місце підрозділів превентивної діяльності у структурі Національної поліції України.

\section{Література}

1. Про утворення та ліквідацію районів : постанова Верховної Ради України від 17 липня 2020 р. № 807-IX. URL: https: //zakon.rada.gov.ua/laws/show/807-20.

2. Про Національну поліцію : Закон України від 2 липня 2015 р. № 580-VIII. URL: http://zakon0.rada. gov.ua/laws/show/580-19.

3. Про запобігання та протидію домашньому насильству : Закон України від 7 грудня 2017 р.
№ 2229-VIII. URL: https://zakon.rada.gov.ua/laws/ show/2229-19.

4. Про затвердження Інструкції з організації роботи підрозділів ювенальної превенції Національної поліції України : наказ МВС України від 19 грудня 2017 р. № 1044. URL: https: / /zakon.rada.gov.ua/laws/ show/z0686-18.

5. Про затвердження Положення про Національну поліцію : постанова Кабінету Міністрів України від 28 жовтня 2015 р. № 877. URL: http://zakon3.rada. gov.ua/laws/show/877-2015.

6. Про Міністерство внутрішніх справ України : постанова Кабінету Міністрів України від 28 жовтня 2015 р. № 878. URL: http://www.kmu.gov.ua/control/ uk/ cardnpd?docid=248608057.

7. Про затвердження положення про патрульну службу : наказ МВС України від 2 липня 2015 р. № 796. URL: http://zakon2.rada.gov.ua/laws/show/ z0777.

8. Про затвердження положення про Департамент превентивної діяльності Національної поліції України : наказ МВС України № 123 від 27 листопада 2015 p. URL: http://zakon4.rada.gov.ua/laws/show/ z0213-94.

9. Про невідкладні заходи із запобігання та протидії домашньому насильству, насильству за ознакою статі, захисту прав осіб, які постраждали від такого насильства : Указ Президента України від 21 вересня 2020 p. № 398/2020. URL: https: //zakon.rada.gov.ua/ laws/show/398/2020.

10. Волокітенко О.І. Основні принципи діяльності підрозділів превентивної служби Національної поліції України. Стан та перспективи розвитку адміністративного права України : матеріали III Міжнародної науково-практичної конференції, м. Одеса, 12 жовтня 2016 р. Одеса : ОДУВС, 2016. 224 с.

11. Волокітенко І.О. Питання взаємодії між працівниками превентивної діяльності та підрозділами Національної поліції України. Науковий вісник Ужгородського національного університету. Серія «Право». 2017. № 43. Т. 4. С. 211-215.

12. Довідник працівника поліції превентивної діяльності : навчальний посібник / кол. авт. ; кер. авт. кол. А.Є. Фоменко. Дніпро : ДДУВС, 2018. 180 с.

13. Функції та структура Національної поліції (Інфографіка). URL: http://portal.lviv.ua/news/ 2015/10/29/funktsiyi-ta-struktura-natsionalnoyipolitsiyi-infografika/

Волокітенко І. О., аспіранm Одеського державного університету внутрішніх справ 